\title{
Association of bacteria with Phaeocystis sp. in McMurdo Sound, Antarctica
}

\author{
Mary Putt ${ }^{1}$, Geraldine Miceli ${ }^{2}$, Diane K. Stoecker ${ }^{3}$ \\ ${ }^{\prime} 713$ Cricklewood Drive, State College, Pennsylvania 16803, USA \\ ${ }^{2}$ Box 1815, Kingston, Rhode Island 02881, USA \\ ${ }^{3}$ Horn Point Environmental Laboratory, PO Box 775, Cambridge, Maryland 21613, USA
}

\begin{abstract}
We present a microscopic study of bacteria and Phaeocystis sp. during the annual bloom in McMurdo Sound, Antarctica. During the initial phases of the bloom when Phaeocystis sp. was actively growing, bacterial abundance and cell size both increased, suggesting that the bacterial community was also actively growing. At 5 and $25 \mathrm{~m}$, the median density of bacteria associated with Phaeocystis sp. colonies ranged from about 2 - to over 11 -fold greater than over an equivalent area of a nearby region of the slide. On 7 out of 8 sampling dates, the length of bacteria associated with Phaeocystis sp. colonies was similar to or larger than pelagic bacteria from the same sample, suggesting that bacterial growth rates were not reduced by their proximity to the alga. In short, rather than bacteriocidal effects sometimes ascribed to Phaeocystis sp. we observed a close association between both pelagic and epiphytic bacteria and Phaeocystis sp. throughout the bloom in McMurdo Sound. Initial results with a strain of Phaeocystis pouchetii (CCMP 628) originally collected in Surinam and grown in culture suggest that differences between the results of this and previous studies might, at least in part, reflect strain differences. As the season progressed, disappearance of Phaeocystis sp. colonies in the upper water column corresponded to the appearance of a large bacterial bloom at and below $100 \mathrm{~m}$ depth. We speculate that in McMurdo Sound, the close alga-bacterial association might enhance remineralization. of Phaeocystis sp. thus reducing the amount of organic material originating from the bloom which ultimately reaches the sediments.
\end{abstract}

KEY WORDS: Phaeocystis sp. Algal-bacterial interaction - Antarctica

\section{INTRODUCTION}

The prymnesiophyte alga Phaeocystis sp. forms massive blooms in temperate and polar regions and is undoubtedly an important contributor both to global primary productivity and to the flux of volatile sulfur compounds from the ocean to the atmosphere (Bates et al. 1987, Lancelot et al. 1987). The fate of Phaeocystis sp. blooms is uncertain. While some protozoa and metazoan zooplankton can graze Phaeocystis sp. (e.g. Admiraal \& van Kamp 1986, Huntley et al. 1987, Tande \& Bamstedt 1987, Weisse \& Scheffel-Moser 1990), others avoid feeding on it, perhaps because of its low nutritional quality (Smith 1988, Verity \& Smayda 1989, Claustre et al. 1990). In some areas, large quantities of Phaeocystis sp. may ultimately sink out of the euphotic zone (Savage \& Hardy 1934, Wassmann et al. 1990).
The relationship between Phaeocytsis sp. and bacteria is somewhat paradoxical. While in the colonial stage that characterizes Phaeocystis sp. blooms, the alga can excrete substantial amounts of photosynthate both as mucilaginous polymers and as small metabolites (Guillard \& Hellebust 1971, Eberlein et al. 1985, Lancelot \& Mathot 1985). However, field populations are also thought to have bacteriocidal properties, particularly during periods of active growth (Sieburth 1959, Barnard et al. 1984, Eberlein et al. 1985, Veldhuis \& Admiraal 1985, Verity et al. 1988, Wassmann et al. 1990, Davidson \& Marchant 1992). Verity et al. (1988) report that bacterial activity and colonization of Phaeocystis sp. increase only during senescence. Inhibition of bacterial activity during active growth of the alga may explain accumulations of DOC during Phaeocystis sp. blooms (Eberlein et al. 1985). 
On the other hand, antibacterial activity in Phaeocystis sp. seems inconsistent with several field studies of blooms in coastal waters of the North Sea (Lancelot \& Billen 1984, Laanbroek et al. 1985, Lancelot \& Mathot 1985, 1987, Billen \& Fontigny 1987). Here, substantial increases in total bacterial biomass, microheterotrophic assimilation of various organic substrates including thymidine, and exoproteolytic activity appear to be coupled to the algal bloom.

Understanding the relationship between bacteria and Phaeocystis sp. is important in understanding the fate of the bloom. High bacterial activity during a bloom could enhance remineralization within the mixed layer of organic material originating from Phaeocystis sp. and possibly facilitate entry of this material into the microbial food web. Alternatively, suppression of bacterial activity in the euphotic zone combined with low direct grazing pressure could increase the probability that a Phaeocystis sp. colony ultimately sinks out of the euphotic zone (Wassmann et al. 1990). To address the in situ relationship between bacteria and Phaeocystis sp. we present detailed microscopic observations made during the development and decline of the annual bloom of this alga in McMurdo Sound, Antarctica. Here, we find evidence suggesting that the bloom is characterised by active bacterial growth along with a strong epibacterial association.

\section{MATERALS AND METHODS}

Sample collection. We collected samples with a 5 I Niskin bottle at 5,25,50,100 and $150 \mathrm{~m}$ between late November and late January 1990-91 from the edge of the annual sea ice on the eastern side of McMurdo Sound, a deep embayment (maximum depth ca 600 to $700 \mathrm{~m})$ in the southwestern Ross Sea $\left(77^{\circ} 30^{\prime} \mathrm{S}, 166^{\circ} \mathrm{W}\right.$, Barry 1988). During the sampling period, the ice edge receded from Cape Bird at the northern end of Ross Island to the vicinity of Tent Island. Our sampling sites were located about 10 to $25 \mathrm{~km}$ west of Ross Island. The current at our sampling sites consistently came from the north; thus we were likely sampling water recently advected into the region from the southwestern Ross Sea (Barry 1988). Although we will discuss our findings in terms of a seasonal trend it is important to note that we did not follow the same water mass throughout the study.

Irradiance profiles. For many profiles, irradiance was measured using a LICOR Model 185B photometer equipped with a cosine sensor. Reported light levels are based on irradiance profiles for that date, or when no irradiance profile was made, from the profile nearest in time to the date of interest.
Chlorophyll analyses. Triplicate samples $(10$ to $500 \mathrm{ml}$ ) were filtered onto $\mathrm{GF} / \mathrm{F}$ filters, extracted in $90 \%$ acetone at $-20^{\circ} \mathrm{C}$ for $24 \mathrm{~h}$ and chlorophyll determined fluorometrically (Parsons et al. 1984).

Phaeocystis sp. abundance. Phaeocystis sp. cells were counted at $640 \times$ using epifluorescence microscopy for samples stained with proflavine and filtered (25 to $100 \mathrm{ml}$ ) onto $1.0 \mu \mathrm{m}$ black polycarbonate filters (Haas 1982). Counts include cells found both in colonies and as individual cells. Cell volume was estimated from linear dimensions using a geometric approximation. At times, colonies of Phaeocystis sp. were visible without magnification. These colonies are referred to as 'macrocolonies'.

Measurements of bacteria. Samples preserved with $1 \%$ glutaraldehyde were stained with DAPI (Porter \& Feig 1980), and either filtered directly (TBAC) or following passage using gravity filtration through a $3.0 \mu \mathrm{m}$ polycarbonate filter ( $<3 \mathrm{BAC})$ onto $0.2 \mu \mathrm{m}$ black polycarbonate filters. We estimated the number of bacteria retained on a $3 \mu \mathrm{m}$ filter (>3BAC) from the difference between TBAC and $\angle 3 B A C$. Filtration generally took place within $2 \mathrm{~h}$ of collection and always within $12 \mathrm{~h}$ of collection. Bacteria were enumerated at $1000 \times$ using Zeiss upright or inverted epifluorescence microscopes either by direct observation or using an image analyzer (Universal Imaging Company in combination with a Cohu Model 6500 CCD camera).

For certain samples, we also enumerated bacteria directly over Phaeocystis sp. colonies ( $\mathrm{n}=8$ to 15 per sample) and over the equivalent area of a randomly selected region in the vicinity of the colony. We estimated an areal density of epibacteria associated with each colony by subtracting the number of bacteria in the adjacent region and normalizing with respect to area. We estimated a 'concentration factor' for each colony by taking the ratio of the abundance of epibacteria (corrected for free bacteria) and pelagic bacteria over an equivalent area.

Changes in cell volume in bacteria from McMurdo Sound largely reflect the relative abundance of rods (Putt et al. 1990, Y. Borsheim unpubl.). As a relative indication of seasonal changes in cell size, we measured the longest dimension of bacteria from 5 and $150 \mathrm{~m}$ using image analysis. Except as noted, the regions chosen for sizing were free of Phaeocystis sp. colonies. Curved celis, which were always a small proportion of the total bacterial community ( $Y$. Borsheim unpub.), were not included because their length is underestimated by the image analysis system which we used. At least 50 cells were sized except in 4 cases where 25 to 40 cells were sized.

Effect of glutaraldehyde on bacteria-alga association. In our field study, we preserved our samples with $1 \%$ glutaraldehyde prior to filtration for 2 reasons. First, 
filtration at an air temperature of about $20^{\circ} \mathrm{C}$ caused some warming of the samples and we were unsure how this might influence association between alga and bacteria or the integrity of the live Phaeocystis sp. colonies. Second, stain intensity seemed greater in fixed compared to unfixed samples.

To examine how fixation with glutaraldehyde might influence the bacteria-alga association we performed an experiment with a culture of Phaeocystis pouchetii (CCMP 628) originally collected in the waters near Surinam and cultured in $\mathrm{f} / 2$ (Guillard \& Ryther 1962) at $20^{\circ} \mathrm{C}$ with selenium addition. A $5 \mathrm{ml}$ sample of a $10 \mathrm{~d}$ old batch culture was filtered onto a slide either without preservation or following preservation with $1 \%$ glutaraldehyde. The number of bacteria associated with 100 randomly selected individual cells was enumerated for each preparation. For the preserved sample, we also enumerated the number of bacteria over macrocolonies of $P$. pouchetii (CCMP 628) and over an equivalent area of a randomly selected region adjacent to the colony.

Statistical analyses. Analyses were performed using STATA. Non-parametric tests were used for group comparisons. Confidence intervals were constructed assuming approximate normality (Larsen \& Marx. 1986). When assumptions of normality seemed unrealistic, we used the interquartile range (the difference between the 75 th and the 25 th percentiles) as a summary measure. In graphical presentations of nonnormal data, we also present 'adjacent' values which are defined as three halves the interquartile range rolled back to where there is data (Tukey 1977).

\section{RESULTS}

\section{Seasonal patterns of chlorophyll and Phaeocystis sp.}

Integrated chlorophyll ( 0 to $150 \mathrm{~m}$ ) increased from ca 20 to $500-600 \mathrm{mg} \mathrm{m}^{-2}$ between November and late December/early January (Fig. 1A). Phaeocystis sp. was initially present in our samples almost exclusively as individual cells. Small 'colonies' of 2, 4 or 8 cells appeared in late November and early December, and large, conspicuous 'macrocolonies' of Phaeocystis sp. became evident in the water column beginning 10 December. These colonies demonstrated buoyancy regulation when placed in a lighted incubator, suggesting that they were physiologically healthy. Phaeocystis $\mathrm{sp}$. was present continuously during our sampling period (Fig. 1B). However, the appearance of macrocolonies coincided with an increase in total cell abundance of Phaeocystis sp. of about 2 orders of magnitude relative to late November/early December (Fig. 1B). Average Phaeocystis sp. cell volume (ca $30 \mu \mathrm{m}^{3}$ ) in late
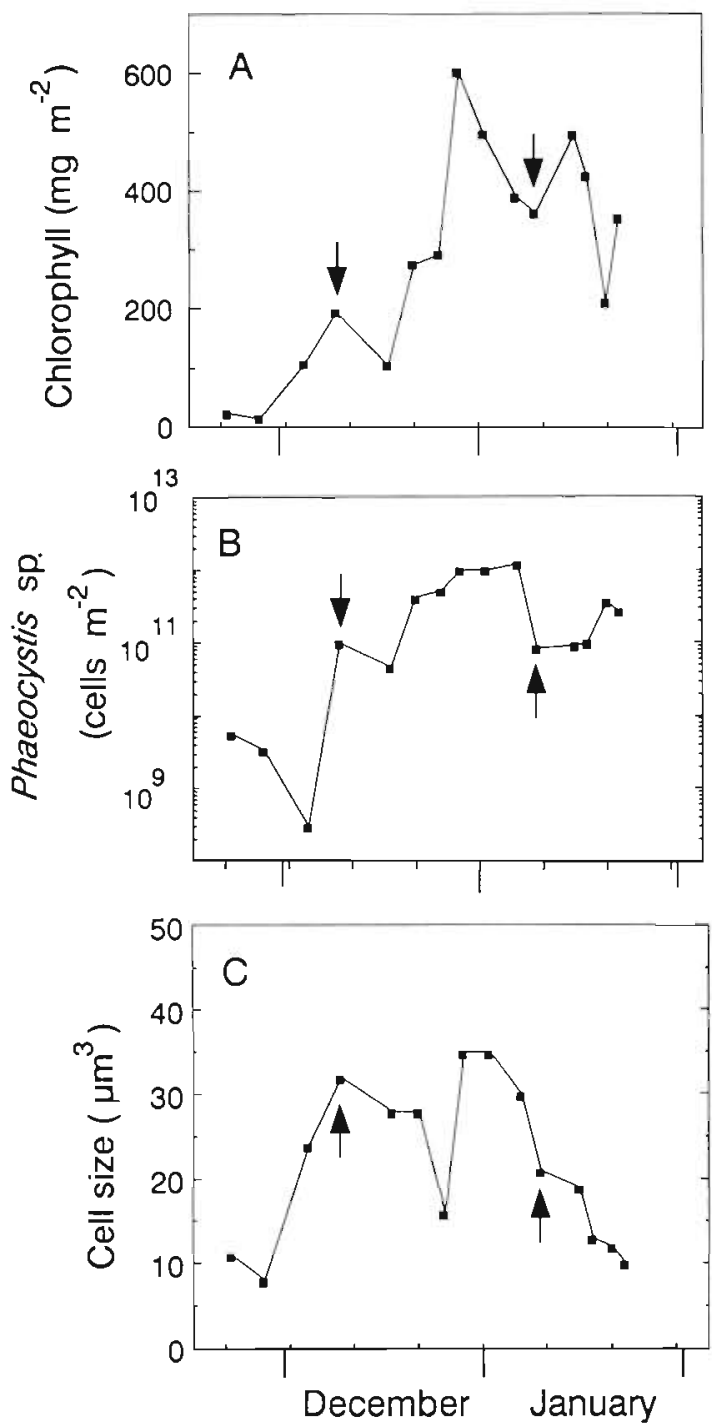

Fig. 1. McMurdo Sound, Antarctica, 1990-91. seasonal patterns of (A) chlorophyll, (B) Phaeocystis sp. abundance and (C) Phaeocystis sp. cell volume. Values were integrated between 0 and $150 \mathrm{~m}$. As indicated by arrows, macrocolonies of Phaeocystis sp. first became evident on 10 December and were rare after 10 January

December/early January was also about 3 times greater than in late November (Fig. 1C). Maximum abundances of Phaeocystis sp. during the 1990-91 season occurred in late December/early January when integrated values were $1 \times 10^{12}$ cells m $\mathrm{m}^{-2}\left(1.3\right.$ to $2.6 \times 10^{4}$ cells ml $\mathrm{m}^{-1}$ at 5 and $25 \mathrm{~m}$ ) (Fig. 1B). Phaeocystis sp. accounted for $97 \%$ of the abundance of phototrophs at the height of the bloom (data not shown).

During January, integrated chlorophyll and Phaeocystis sp. abundance both decreased, but remained higher than pre-bloom values (Fig. 1A, B). After 10 January, few 'macrocolonies' were evident although individual Phaeocystis sp. was still present at ca $10^{11}$ cells 
$\mathrm{m}^{-2}\left(10^{2}\right.$ to $10^{3}$ cells $\mathrm{ml}^{-1}$ at 5 and $25 \mathrm{~m}$ with somewhat higher numbers deeper in the water column). Phaeocystis sp. cell size decreased steadily until pre-bloom values were reached in late January (Fig. 1C).

\section{Seasonal patterns of bacterial abundance and size}

Overall, bacterial abundance integrated over the upper $150 \mathrm{~m}$ increased throughout the development of the Phaeocystis sp. bloom between 10 December and 10 January (Fig. 2A). During the bloom, bacterial length at $5 \mathrm{~m}$ was generally larger than in pre-bloom
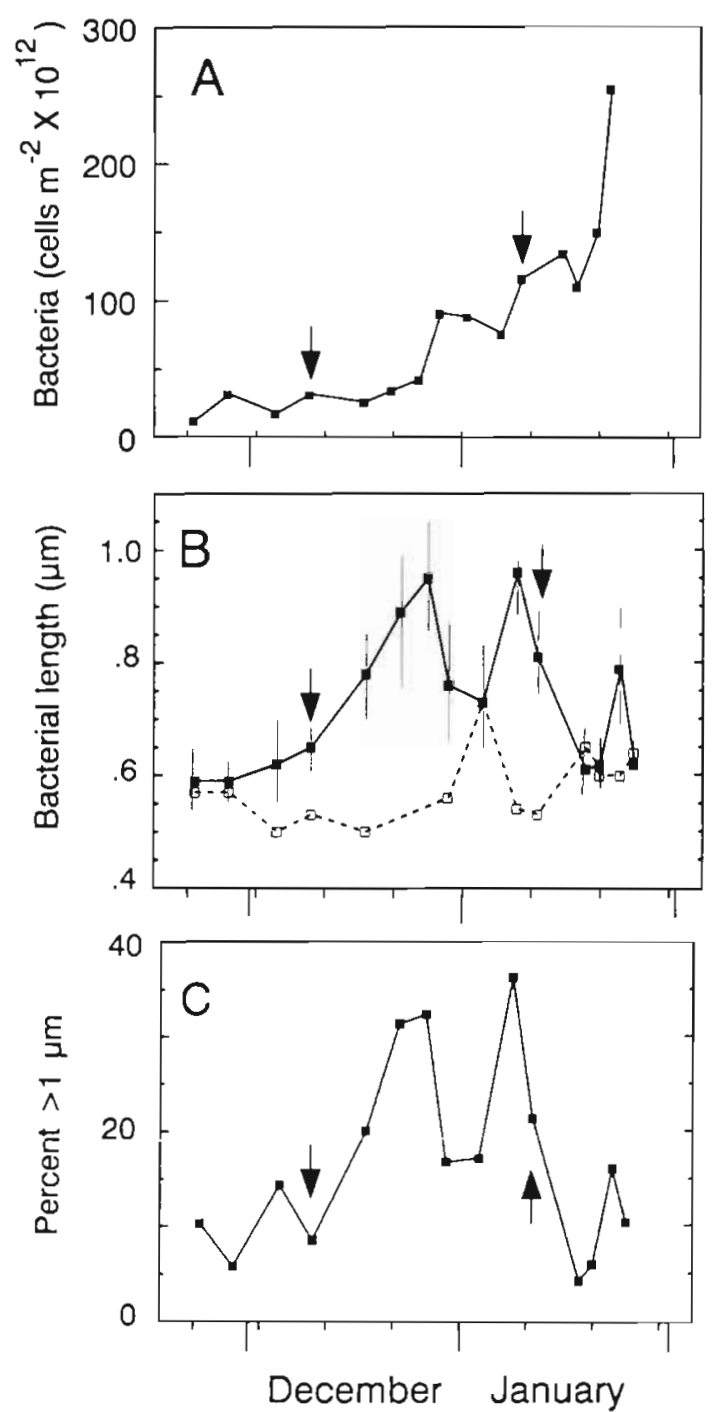

Fig. 2. McMurdo Sound, Antarctica (1990-91): seasonal changes in (A) bacterial abundance integrated over the upper $150 \mathrm{~m}$ and $(B)$ cell length at $5 \mathrm{~m}$ ( $\mathrm{a})$ and $150 \mathrm{~m}(\mathrm{a})$, and $(\mathrm{C})$ fraction of bacteria $(\%)$ at $5 \mathrm{~m}$ greater than $1 \mu \mathrm{m}$ in length. Bars are $95 \%$ CI. Samples from $150 \mathrm{~m}$ on 22 December and 26 December were not sized. Arrows as in Fig. 1 samples with mean bacterial length ranging from 0.73 to $0.95 \mu \mathrm{m}$. In contrast, mean bacterial length at $5 \mathrm{~m}$ was less than $0.65 \mu \mathrm{m}$ prior to bloom onset. The increase in mean length partly reflected increases in the 'sub-population' of the largest bacteria. Prior to bloom onset, less than $15 \%$ of the bacteria exceeded $1 \mu \mathrm{m}$ in length; on 3 sampling dates during the bloom over $30 \%$ of the bacteria exceeded $1 \mu \mathrm{m}$ in length (Fig. 2C). After 10 January, bacterial abundance continued to increase. No consistent seasonal pattern in bacterial length occurred at $150 \mathrm{~m}$ (Fig. 2B).

\section{Association of bacteria with Phaeocystis sp. during bloom development}

In November and December during bloom development, maximum values of chlorophyll occurred at or above $50 \mathrm{~m}$ and the $0.1 \%$ light level (Fig. 3A, B, C). Depth profiles of bacteria and chlorophyll were similar at this time of year. Prior to and at the onset of bloom initiation, most bacteria passed through a $3 \mu \mathrm{m}$ filter (Figs. 3A, B \& 4). However, by late December substantial numbers of bacteria in the upper water column (i.e. at or above $50 \mathrm{~m}$ ) did not pass a $3 \mu \mathrm{m}$ filter (Figs. $3 \mathrm{C} \&$ $4)$. In late December the $>3 \mathrm{BAC}$ reached a maximum of $22 \times 10^{12}$ cells $\mathrm{m}^{-2}$ or $25 \%$ of the total bacteria above $150 \mathrm{~m}$ (Fig. 4). At the height of the bloom between 26 December and 2 January, an average of $37 \pm 16 \%$ ( $S D, n=6$ ) of the total bacteria at 5 and $25 \mathrm{~m}$, did not pass a $3 \mu \mathrm{m}$ filter (data not shown).

Direct microscopic observation suggested that the increase in $>3$ BAC during December was in large part due to association of bacteria with Phaeocystis sp. macrocolonies. Our estimates of the areal concentrations of epibacteria over Phaeocystis sp. macrocolonies were corrected for pelagic bacteria. Thus a value of zero indicates that the concentration of bacteria over the colony was no larger than over an adjacent region of the slide. At both 5 and $25 \mathrm{~m}$, almost every colony had nonzero epibacteria values during December (Fig. 5).

Similarly, 'concentration factors' $[\mathrm{CF}=$ (no. over colony - no. free)/no. free] in excess of 0 indicate that the density of bacteria associated with Phaeocystis sp. colonies (corrected for 'free' bacteria) was higher than the density of bacteria in a nearby region of the slide (Fig. 6). Particularly at $5 \mathrm{~m}$, concentration factors for individual colonies in excess of 20 were not uncommon. For both $5 \mathrm{~m}$ and $25 \mathrm{~m}$, concentration factors were statistically different for the different dates ( $p<0.06$ for $5 \mathrm{~m}$, and $\mathrm{p}<0.08$ at $25 \mathrm{~m}$, using a KruskalWallis test). At $5 \mathrm{~m}$, the smallest median concentration factor was 2.4 on 10 December and the largest was 8.9 on 22 December. At $25 \mathrm{~m}$, the smallest median concentration factor was 5.2 on 29 December and the largest was 11.3 on 14 December. 

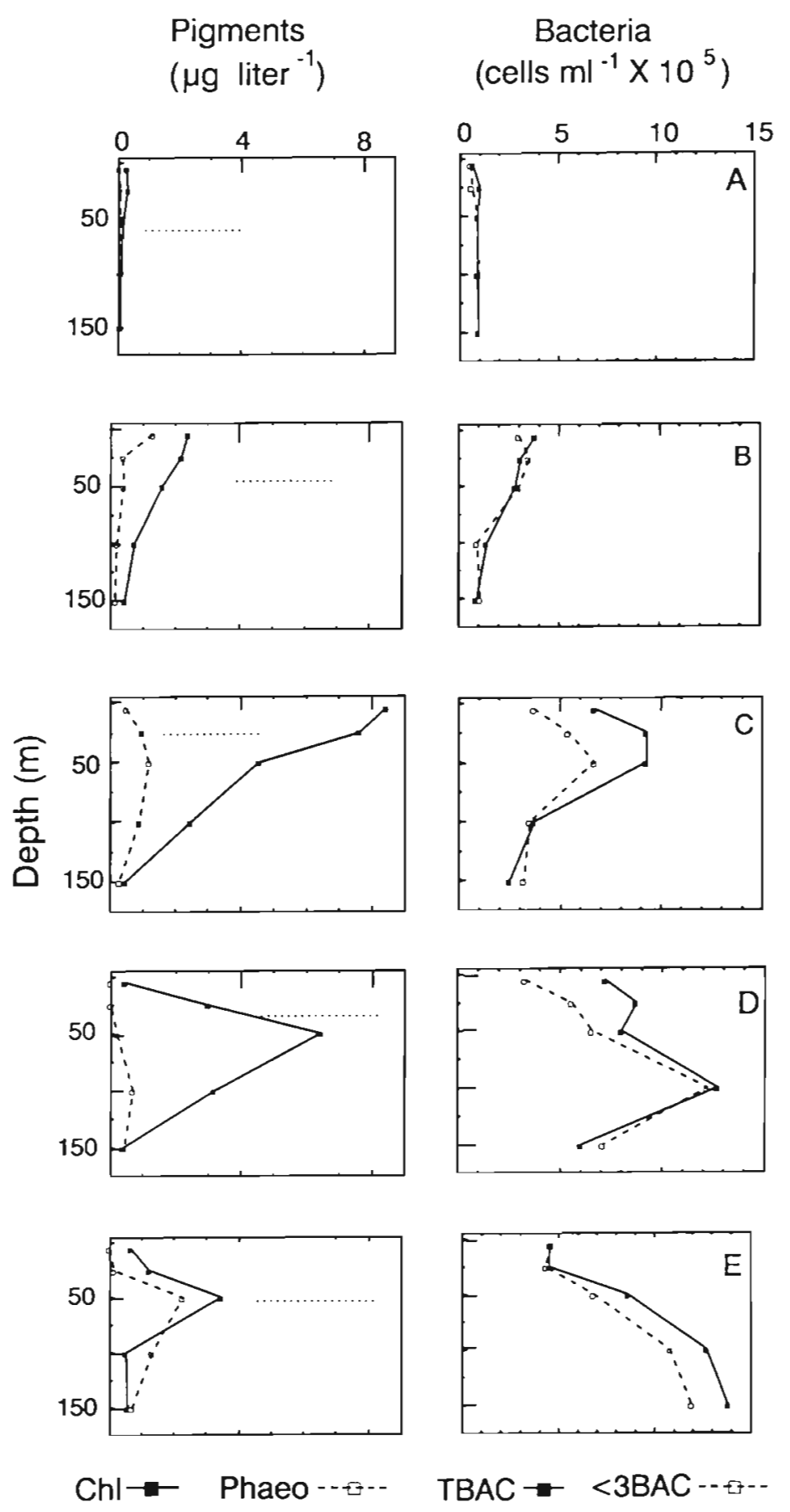

TBAC $-<3 B A C--$

Fig. 3. McMurdo Sound, Antarctica, 1990-91: representative depth profiles of chlorophyll (Chl) and phaeopigments (Phaeo), total bacteria (TBAC) and bacteria which passed a $3 \mu \mathrm{m}$ filter ( $\angle 3 B A C$ ), on (A) 28 November, (B) 10 December, (C) 29 December, (D) 10 January and (E) 21 January. Horizontal dotted line indicates approximate position of $0.1 \% I_{0}$

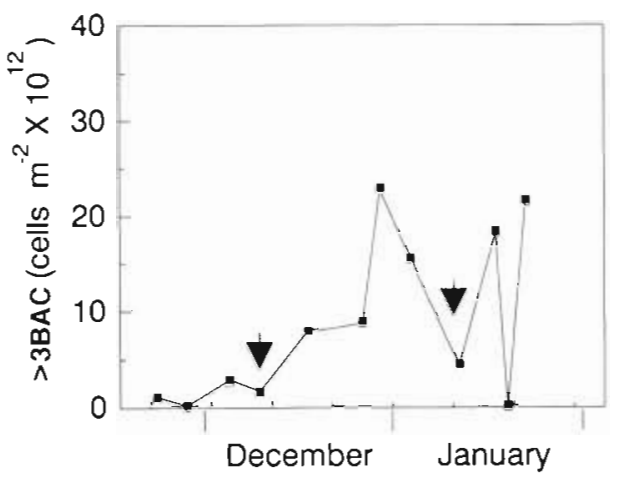

Fig. 4. McMurdo Sound, Antarctica, 1990-91: seasonal changes in the difference $(>3 \mathrm{BAC}$ ) between bacteria which passed a $3 \mu \mathrm{m}$ filter ( $\angle 3 \mathrm{BAC}$ ) and total bacteria (TBAC). Values were integrated between 0 and $150 \mathrm{~m}$

\section{Effect of glutaraldehyde on the bacteria-alga association}

The concentration of bacteria in the Phaeocystis pouchetii culture was about $1.5 \times 10^{8}$ cells $\mathrm{ml}^{-1}$, i.e. about 2 orders of magnitude higher than in McMurdo Sound. For a sample preserved with glutaraldehyde, a Wilcoxon signed rank test (non-parametric equivalent to the paired $t$-test) indicated significant differences between the concentration of bacteria directly over the colony and adjacent to the colony. On average the culture had 12 more bacteria per $1000 \mu \mathrm{m}^{2}$ over the adjacent region than directly over the colony. Thus the result was opposite to what we observed in the field samples. The median ratio of bacteria over colonies compared to adjacent regions of the slide was 0.54 (interquartile range of 0.4 to 1.0 ).

We were unable to use the same technique to examine unpreserved samples because live colonies of this strain of Phaeocystis pouchetii disintegrated during filtration. However, we did examine the association of bacteria with individual cells in unpreserved and preserved samples (Table 2). The mean number of bacteria per cell in the unpreserved sample was 1.13 compared to 1.76 in the preserved sample. The nonoverlapping $95 \%$ confidence intervals indicate that the differences are statistically significant $(p<0.05)$ (Table 2). On average, the number of bacteria per cell was $56 \%$ greater in the preserved compared to the unpreserved sample.
Except for 10 December, the first date that we observed substantial numbers of macrocolonies, the length of the epibacteria was similar to or greater than the length of the pelagic bacteria (Table 1 j.

\section{Association of bacteria and chlorophyll post-bloom}

As of 10 January, when macrocolonies of Phaeocystis sp. were greatly diminished in abundance, maximum 

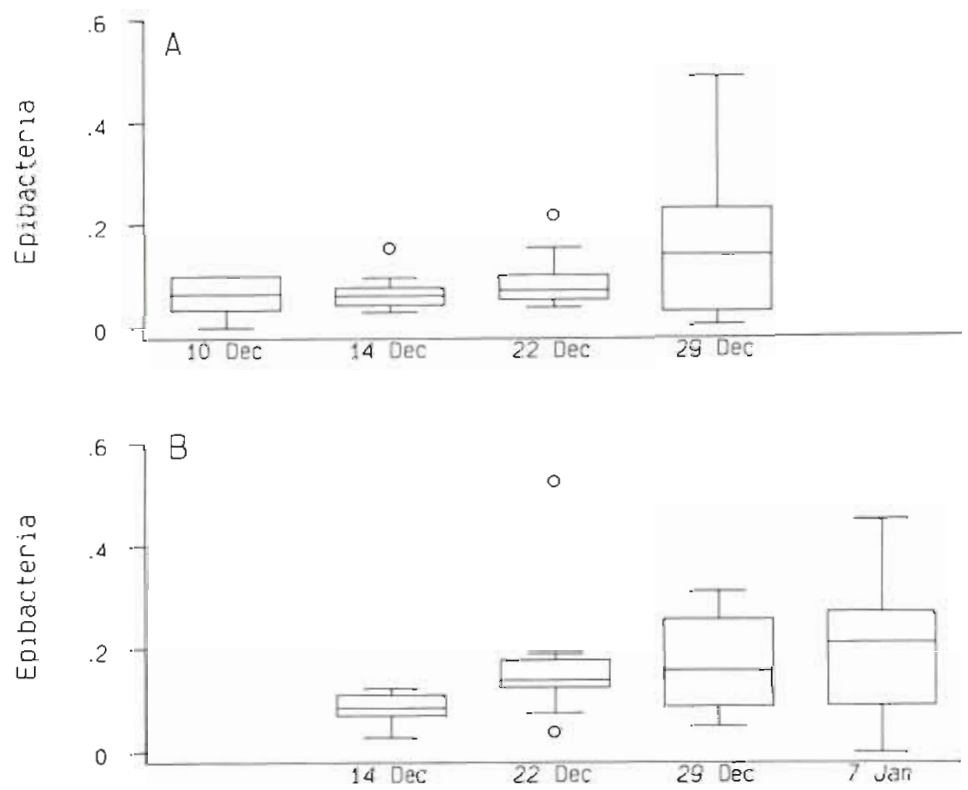

Fig. 5. McMurdo Sound, Antarctica, 1990-91: areal density of epibacteria (corrected for free bacteria) associated with Phaeocystis sp. colonies at (A) $5 \mathrm{~m}$ and (B) $25 \mathrm{~m}$. The line in the middle of each box is the median of the data. The box encloses the interquartile range. The lines emerging from the box extend to the upper and lower adjacent values.

(O) Data points outside the adjacent values
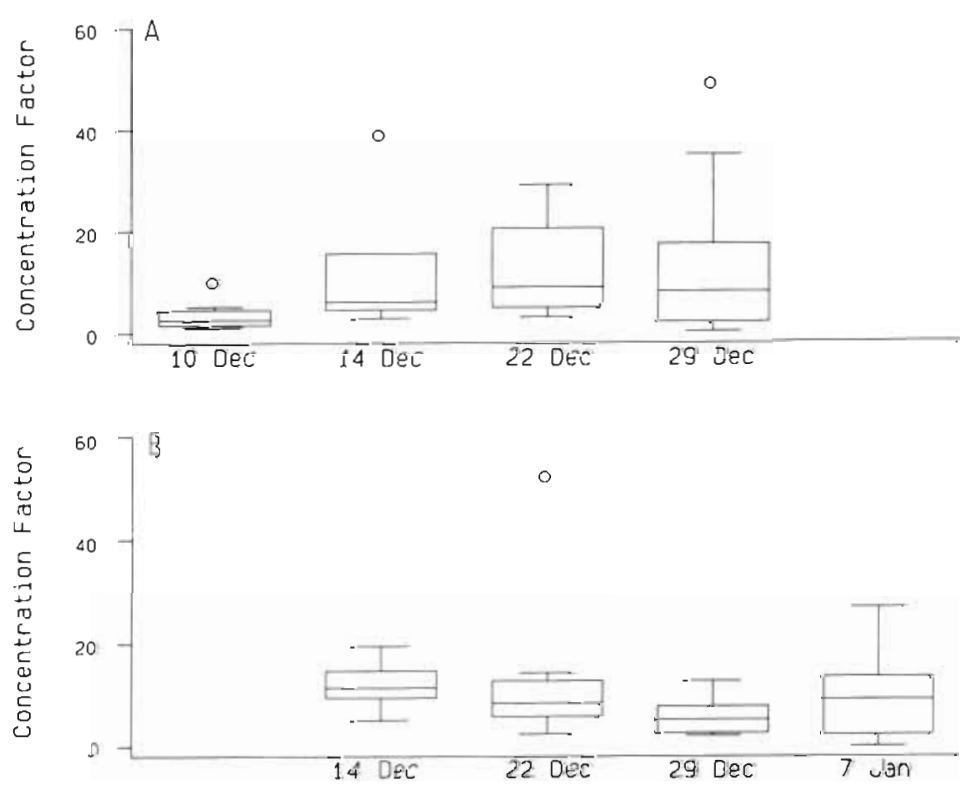

Fig. 6. McMurdo Sound, Antarctica, 1990-91. concentration factor of epibacteria (corrected for free bacteria) associated with Phaeocystis sp. colonies with respect to free bacteria, at (A) $5 \mathrm{~m}$ and (B) $25 \mathrm{~m}$. The line in the middle of eachbox is the median of the data. The box encloses the interquartile range. The lines emerging from the box extend to the upper and lower adjacent values. (O) Data points outside the adjacent values values of chlorophyll and phaeopigments occurred at $50 \mathrm{~m}$, a depth which was near or below the $0.1 \%$ light level at this time of year (e.g. Fig. 3D, E). Peaks in bacterial abundance occurred well below the chlorophyll maximum. Abundances of bacteria in our deepest samples increased until the end of our field season. The highest abundance of bacteria in our study $\left(60 \times 10^{5}\right.$ cells $\left.\mathrm{ml}^{-1}\right)$ occurred at $150 \mathrm{~m}$ on our last sampling date (23 January 1991; not shown). On this date $73 \%$ of the total bacteria integrated over the upper $150 \mathrm{~m}$ occurred between 100 and $150 \mathrm{~m}$.

Although the seasonal pattern of $>3 \mathrm{BAC}$ became somewhat erratic as the season progressed, substantial numbers of $>3 \mathrm{BAC}$ occurred in late January (Fig. 4). In the upper water column we observed epibacteria associated with pennate diatoms (e.g. Nitzschia spp.) and detrital particles (Fig. 3D). At depth, clumps of bacteria appeared that were not associated with any defined particles (Fig. 3E).

\section{Relationship between chlorophyll and bacteria}

Bacterial density plotted as a function of chlorophyll suggests that the abundance of bacteria during the post-bloom period tended to be higher than during the pre- or midbloom periods for a similar chlorophyll levels (Fig. 7).

Based on the depth profiles of chlorophyll (e.g. Fig. 3E), anomalously high bacterial numbers seemed to occur at depth in the post-bloom period. To examine this further, we performed a linear regression using ordinary least squares of the relationship between ln (bacterial abundance) and In (chlorophyll concentration) using only samples collected up until 10 January (i.e. the period before the bloom and during bloom development) (Fig. 7). If a linear relationship holds, then the prediction interval should with $95 \%$ certainty cover the true number of bacteria for a fixed value of chlorophyll. We had a total of 74 samples, with 25 from the postbloom period. If the data from the post-bloorn period were consistent with the linear relationship predicted for the pre- and midbloom data, then by chance alone, we would expect that roughly 4 points from the entire data set might lie outside the $95 \%$ prediction interval. We would expect no more than 2 
Table $1.95 \%$ confidence intervals for the mean length of bacteria in regions free of Phaeocystis pouchettii colonies ('pelagic' bacteria) compared to bacteria associated with Phaeocystis sp. colonies ('epibacteria')

\begin{tabular}{|c|c|c|c|}
\hline \multirow{2}{*}{ Date } & \multirow{2}{*}{$\begin{array}{l}\text { Depth } \\
(\mathrm{m})\end{array}$} & \multicolumn{2}{|c|}{ Length $(\mu \mathrm{m})$} \\
\hline & & Pelagic bacteria & Epibacteria \\
\hline 10 December $^{d}$ & 5 & $0.61,0.69$ & $0.42,0.50$ \\
\hline 17 December & 5 & $0.70,0.86$ & $0.64,0.76$ \\
\hline 22 December & 5 & $0.75,0.99$ & $0.71,0.83$ \\
\hline 26 December & 25 & $0.71,0.85$ & $0.81,1.05$ \\
\hline 26 December & 100 & $0.56,0.68$ & $0.56,0.76$ \\
\hline 2 January ${ }^{d}$ & 5 & $0.63,0.83$ & $1.12,1.42$ \\
\hline 2 January ${ }^{d}$ & 100 & $0.58,0.70$ & $1.10,1.25$ \\
\hline 10 January & 5 & $0.73,0.89$ & $0.67,0.83$ \\
\hline \multicolumn{4}{|c|}{${ }^{a}$ Non-overlapping confidence intervals } \\
\hline
\end{tabular}

Table 2. 95\% confidence interval for the number of bacteria associated with individual cells in live and preserved $(1 \%$ glutaraldehyde) samples for Phaeocystis pouchetii (CCMP 628) culture grown at $20^{\circ} \mathrm{C}$

\begin{tabular}{|cc|}
\hline Live & Preserved \\
\hline $0.92,1.34$ & $1.50,2.00$ \\
\hline
\end{tabular}

points to be from the post-bloom period. In fact, we observed 10 points outside the $95 \%$ prediction interval; of these 7 were from the post-bloom period. Of the 7 points from the post-bloom period which exceed the $95 \%$ prediction interval, 4 (shown inside the hatched rectangle in Fig. 7) are from depths of 100 to $150 \mathrm{~m}$ This analysis lends weight to the idea that for a particular chlorophyll value, the number of bacteria at depth in the post-bloom period is higher than during bloom development.

\section{DISCUSSION}

Evidence that Phaeocystis sp. inhibits bacterial growth in situ originated with Sieburth (1959) who showed that concentrates of Phaeocystis sp. produce a water-soluble compound which inhibits the growth of several bacterial isolates (Sieburth 1960, 1961). The antibiotic compound, later shown to be acrylic acid, is a product of the decomposition of dimethylsulfoniopropionate (DMSP) to dimethylsulfide (DMS) (Sieburth 1960, Ishida 1968). Sieburth (1959) also reported that surface seawater samples filtered through a Millipore filter became turbid while unaltered samples (presumably containing Phaeocystis sp.) remained clear, and concluded that Phaeocystis sp. would inhibit the growth of natural communities of bacteria. Both Guillard \& Hellebust (1971) and Davidson \& Marchant (1987) subsequently confirmed that cultures of Phaeocystis sp. produce acrylic acid and reported that actively growing cultures had low concentrations of bacteria. Davidson \& Marchant (1987) suggested that this reflected the antibacterial activity of acrylic acid excreted by Phaeocystis sp.

During our study the Phaeocystis sp. bloom went through several distinct stages. In early December, the appearance of macrocolonies along with rapid increases in cell number and cell size suggested that the alga was in a period of active growth (cf. Peperzak 1993). Studies of the photosynthetic characteristics of Phaeocystis sp. from McMurdo Sound also indicate that the alga is physiologically healthy during initial bloom stages (Palmisano et al. 1986). By 10 January macrocolony abundance and cell size were both greatly decreased as the alga apparently entered a different part of its life cycle. It is not clear what environmental factor causes the change in morphology and presumably growth rate, since concentrations of major
Fig. 7. McMurdo Sound, Antarctica, 1990-91: relationship between $\ln$ (chlorophyll concentration) and In (TBAC abundance) for 23 November to 5 December ( $(0), 10$ December to 7 January ( $\Delta$ ) and 10 January to 23 January $(\square)$. The continuous line is the least squares fit to the data for all data up until 7 January where $\ln ($ TBAC $)=0.42 \ln (\mathrm{Chl})+12.3\left(\mathrm{r}^{2}=0.55\right)$ Dotted lines are the $95 \%$ prediction interval. The 4 points inside the dashed box were collected between 100 and $150 \mathrm{~m}$ between 16 and 23 January. The remaining 3 points from 10 to 23 January which are outside the $95 \%$ prediction interval were collected between 10 and 21 January at $5 \mathrm{~m}$

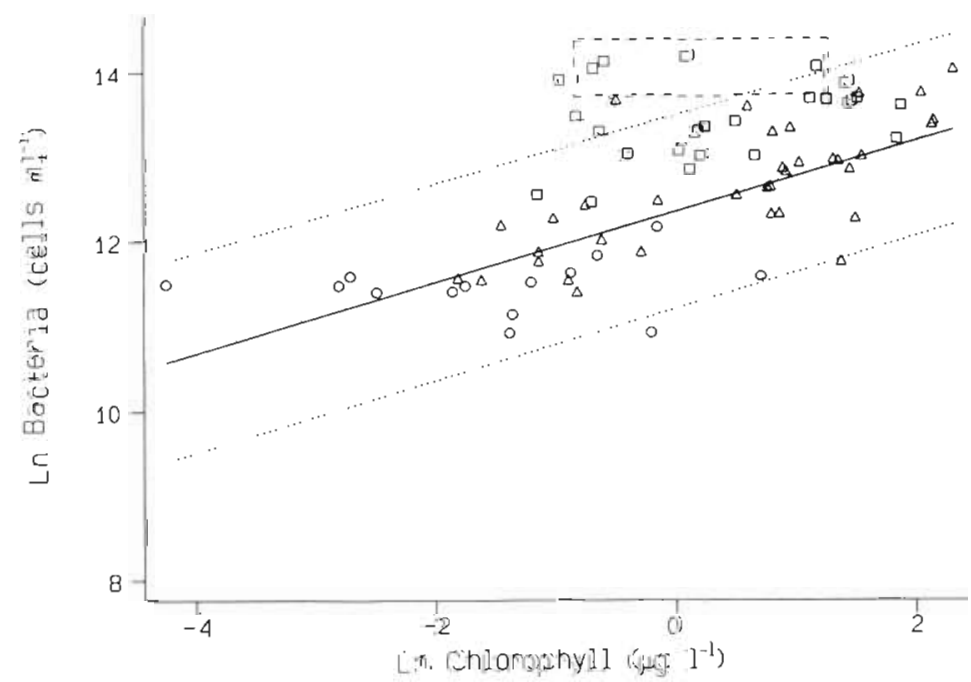


nutrients remain high and temperature fluctuations in McMurdo Sound are small during this period (Littlepage 1965, Barry 1988).

We found no indication of bacteriocidal activity at any time during the Phaeocystis sp. bloom in McMurdo Sound. Both abundance and size of bacteria increased throughout the period of active Phaeocystis sp. growth in December. Similar patterns were found in the previous year (Putt et al. 1990). In nature, bacterial size is positively correlated with growth rate (Ammerman et al. 1984) and negatively correlated with protozoan grazing (because protozoa selectively graze large bacteria; e.g. Chrzanwoski et al. 1991). Protozoan bacterivory in McMurdo Sound is negligible in early December and, if anything, increases during the bloom (Putt et al. 1990, 1991, Moisan et al. 1991). Hence increased bacterial size likely reflects increased growth rates of bacteria during the development of the Phaeocystis sp. bloom. Uptake of thymidine also increases following the onset of the Phaeocystis sp. bloom in McMurdo Sound (Kottmeier et al. 1987; see also Fuhrman \& Azam 1980). In the North Sea, bacterial abundance and metabolic activity increase following the onset of the Phaeocystis sp. bloom (Lancelot \& Billen 1984, Billen \& Fontigny 1987).

An intriguing aspect of our study is that the increased bacterial abundance during the Phaeocystis sp. bloom appeared, at least in part, to reflect epibacteria associated with Phaeocystis $\mathrm{sp}$. colonies. At midbloom, concentrations of bacteria were often more than 8-fold greater over Phaeocystis sp. macrocolonies than over adjacent regions of the filter, and more than one-third of the total bacteria above $25 \mathrm{~m}$ were associated with particles which did not pass through a $3 \mu \mathrm{m}$ filter (probably Phaeocystis sp. colonies to a large extent). Could this apparent association of bacteria with Phaeocystis sp. be an artifact of preservation of our samples with gluataraldehyde? In our 'control' experiment, we found that preservation increased the association of bacteria with individual algal cells of a Phaeocystis pouchetii culture by about $60 \%$ compared to a live sample. However, in this culture where concentrations of bacteria were roughly 2 orders of magnitude higher than in McMurdo Sound, concentrations of bacteria over $P$. pouchetii colonies were actually lower than over adjacent regions of the slide. Together these observations suggest that preservatives may change the 'stickiness' of individual algal cells in some strains of Phaeocystis sp. However, it seems unlikely that preservation with glutaraldehyde would alone cause the very high degree of association between the alga and bacteria which we observed in our field study.

Differential filtration is also not a precise method of measuring epibacterial association. Some epibacteria likely become dislodged during filtration, hence in- creasing the apparent number of bacteria passing through a $3 \mu \mathrm{m}$ filter. On the other hand, some pores may become clogged by particles such as the macrocolonies, thus decreasing the apparent number of bacteria passing through a $3 \mu \mathrm{m}$ filter. Like many field measurements, our estimates of the degree of association between alga and bacteria include errors which are difficult to quantify. Despite this, it seems clear that apparently healthy Phaeocystis sp. colonies were often heavily colonized by bacteria. These bacteria were similar in size or larger than pelagic bacteria, suggesting that the growth rates of the epibacteria were not negatively affected by their proximity to the mucilaginous matrix of Phaeocystis sp., where concentrations of acrylic acid are presumably higher than the average concentration for seawater.

To our knowledge, this is the first study to document extensive epibacterial colonization of Phaeocystis sp. throughout a spring bloom. It is possible that the Phaeocystis sp. strain in McMurdo Sound differs physiologically from previously studied strains. Evidence for this comes from our 'control' study with Phaeocystis pouchetii (CCMP 628). Although this culture was $10 \mathrm{~d}$ old, it had not developed a strong epibacterial association. In the field under conditions very similar to the present study, Davidson \& Marchant (1992) found that the appearance of the P. pouchetii bloom in Prydz Bay, Antarctica, coincided with a decline in bacterial concentration. Differences in the temperature tolerances and rate of production of sulfur compounds in Phaeocystis spp. from polar and temperate regions have also been noted (Guillard \& Hellebust 1971, Gibson et al. 1990).

It is also possible that associations similar to what we observed in McMurdo Sound were overlooked, perhaps because of methodology. For example, studies of bacteria associated with the Phaeocystis sp. bloom in the North Sea have assumed that the contribution of epibacteria to total bacteria production is small, based on results of an unpublished study apparently indicating that thymidine uptake for particles $>2 \mu \mathrm{m}$ in size was negligible (Lancelot \& Mathot 1985). Assimilation of thymidine could underestimate epibacterial metabolism if the epibacteria did not assimilate thymidine. A substantial fraction of metabolically active free bacteria do not assimilate thymidine (Douglas et al. 1987).

In contrast, in a nearby study of coastal waters of the Netherlands, Laanbroek et al. (1985) reported that over $60 \%$ of total thymidine uptake was collected on a $3 \mu \mathrm{m}$ filter during a Phaeocystis sp. bloom. Laanbroek et al. (1985) state that the high proportion of thymidine uptake associated with a $3 \mu \mathrm{m}$ filter was not due to increased proportions of epibacteria but do not provide data or give details of their fixation or filtration procedures for the determination of epibacteria. With regard 
to microscopy, Phaeocystis sp. may disintegrate after fixation in some preservatives (Rousseau et al. 1990). Because we filtered within $12 \mathrm{~h}$ of sampling we may have more readily detected epibacteria associated with Phaeocystis sp. than previous studies.

How do we reconcile our results with those of Sieburth (1959)? Later studies (Sieburth 1961) showed that the pH optimum for the antibiotic effects of acrylic acid was 5 . The $\mathrm{pH}$ of seawater (ca 7.5 to 8.5 ) is thus higher than the $\mathrm{pH}$ optimum for antibacterial activity of acrylic acid. Guillard \& Hellebust (1971) estimated that the concentration of acrylic acid released into seawater through excretion would be $0.007 \mu \mathrm{g} \mathrm{ml}^{-1}$ during an algal bloom. At pH 6.5, minimal inhibiting concentrations of acrylic acid for 39 bacterial strains ranged from $12 \mu \mathrm{g} \mathrm{ml}^{-1}$ to $50000 \mu \mathrm{g} \mathrm{ml}^{-1}$. Even if substantial amounts of acrylic acid were released through mechanisms other than algal excretion, it seems likely that the concentration of acrylic acid in situ would be substantially lower than that needed to inhibit bacterial growth (see also Palmisano et al. 1986).

We can only speculate as to the potential importance of a strong bacteria-alga association during a Phaeocystis sp. bloom. DMS, the compound produced with acrylic acid during decomposition of DMSP, is a major volatile sulfur compound in surface seawater (Barnard et al. 1984). Phaeocystis sp. blooms in Antarctic waters are associated with the highest levels of DMS ever recorded but with relatively low ratios of DMSP:DMS (Gibson et al. 1990). DMS may be produced through release of DMSP by algae and subsequent conversion to DMS via enzymatic processes (Dacey \& Blough 1987). Ironically, bacteria may actually produce the 'bacteriocidal compound' acrylic acid during decomposition of DMSP (Dacey \& Blough 1987). Because concentrations of DMSP in the vicinity of the colony are presumably higher than the average concentration in seawater, epibacteria associated with colonial Phaeocystis sp. might be particularly effective at metabolising DMSP to DMS (Dacey \& Blough 1987). Efficient conversion of DMSP to DMS by bacteria might contribute to the low DMSP: DMS ratio reported in Antarctic waters during a Phaeocystis sp. bloom (Gibson et al. 1990).

With regard to carbon, Phaeocystis $\mathrm{sp}$. grown in axenic culture stores photosynthate in its mucilaginous matrix during the day for subsequent nighttime protein synthesis (Lancelot et al. 1986). Production of mucilage during the day and subsequent mobilisation during the night also occurs in nature where it has been assumed that nighttime metabolism reflects algal processes (Lancelot \& Mathot 1985, 1987, Lancelot et al. 1987). As with sulfur, we do not know how a strong epibacterial association might interact with algal metabolism.

Previous studies suggest that large amounts of Phaeocystis sp. may also sink out of the mixed layer
(Wassmann et al. 1990, and see Putt 1991). Algabacteria interactions may influence the proportion of a sinking Phaeocystis sp. bloom which ultimately reaches the sediments. In mid- to late January reduced macrocolony abundance in the upper water column coincided with the appearance of chlorophyll and phaeopigment maxima at lower depths. Between 50 and $150 \mathrm{~m}$, individual Phaeocystis sp. cells were still fairly abundant (typically $10^{3}$ to $10^{4}$ cells $\mathrm{ml}^{-1}$ ) (data not shown). The most likely source of the pigments at depth was sinking Phaeocystis sp. blooms. However, since we did not follow a single water mass, we cannot make this conclusion with certainty. In any event, the deepening of the pigment maxima was accompanied by the development of a bacterial bloom at relatively shallow depths $(100$ to $150 \mathrm{~m})$. Assuming that the source of organic material supporting this bacterial bloom was indeed Phaeocystis sp., development of the bacterial bloom at relatively shallow depth might have been facilitated by the epibacterial colonisation of Phaeocystis sp. colonies. At least in McMurdo Sound, the net result of the close association between epibacteria and Phaeocystis sp. colonies might be to enhance remineralization, thus reducing the degree to which sinking blooms of this alga contribute to the flux of carbon to the sediments.

Acknowledgements. We thank Tiffany Moisan, Dan Gustafson, Linda Davis, the staff of the Eklund Biological Laboratory and the VXE-6 for their generous contributions to the research and analysis portion of our study, and the annonymous reviewers for their comments. $Y$ Borsheim provided information about bacterial morphology based on his electron microscopy work. Algal cultures were supplied by the Guillard-Provosoli Center for the Culture of Marine Phytoplankton. Old Dominion Unuversity supplied many of the facilities during the data analysis portion of this study. Research supported by NSF-DPP 9096155 (M.P.).

\section{LITERATURE CITED}

Admiraal, W., van Kamp, L. A. H. (1986). Significance of tintinnid grazing during blooms of Phaeocystis pouchetii (Haptophyceae) in Dutch coastal waters. Neth. J. Sea Res. 20: $61-66$

Ammerman, J. W., Fuhrman, J. A., Hagström, A., Azam, F. (1984). Bacterioplankton growth in seawater: I. Growth kinetics and cellular characteristics in seawater cultures. Mar. Ecol. Prog. Ser. 18: 31-39

Barnard, W. R. Andreae, M. O., Iverson R. L. (1984). Dimethylsulfide and Phaeocystis pouchetii in the southeastern Bering Sea. Cont. Shelf Res. 3: 103-113

Barry, J. P. (1988). Hydrographic patterns in McMurdo Sound, Antarctica, and their relationship to local benthic communities. Polar Biol. 8: 377-391

Bates, T. S., Charlson, R. J., Gammon, R. H. (1987). Evidence for the climatic role of marine biogenic sulfur. Nature 329: $319-321$ 
Billen, G., Fontigny, A. (1987). Dynamics of a Phaeocystisdominated spring bloom in Belgian coastal waters. II. Bacteria dynamics. Mar. Ecol. Prog. Ser. 37: 249-257

Borsheim, K. Y., Bratbak, G., Heldal, M. (1990). Enumeration and biomass estimation of planktonic bacteria and viruses by transmission electron microscopy. Appl environ. Microbiol. 56: 352-356

Chrzanowski, T. H. , Simek, K. (1990). Prey-size selection by freshwater flagellated protozod. Limnol. Oceanogr. 35: $1429-1436$

Claustre, H., Poulet, S. A., Williams, R., Marty, J.-C., Coombs, S., Ben Mlih, F., Hapette, A. M., Martin-Jezequel, V. (1990). A biochemical investigation of a Phaeocystis sp. bloom in the Irish Sea. J. mar. biol. Ass. U.K. 70: 197-207

Dacey, J. W. H., Blough, N. V (1987). Hydroxide decomposition of dimethylsulfoniopropionate to form dimethylsulfide. Geophysical Res. Lett. 14: 1246-1249

Davidson, A. T , Marchant, H. J. (1987). Binding of manganese by Antarctic Phaeocystis pouchetii and the role of bacteria in its release. Mar. Biol. 95: 481-487

Davidson, A. T., Marchant, H. J. (1992). Protist abundance and carbon concentration during a Phaeocystis-dominated bloom at an Antarctic coastal site. Polar Biol. 12: 387-395

Douglas, D., Novitsky, J., Fournier, R. O. (1987). Microautoradiography-based enumeration of bacteria with estimates of thymidine-specific growth and production rates. Mar. Ecol. Prog. Ser. 36: 91-99

Eberlein, K. M., Leal, T., Hammer, K. D., Hickel, W. (1985). Dissolved organic substances during a Phaeocystis pouchetii bloom in the German Bight (North Sea). Mar. Biol. 89: 311-316

Fuhrman, J. A., Azam, F. (1980). Bacterioplankton secondary production estimates for coastal waters of British Columbia, Antarctica, and California. Appl environ. Microbiol. 39: 1085-95

Gibson, J. A. E., Garrick, R. C., Burton, H. R., McTaggart, A. R. (1990). Dimethylsulfide and the alga Phaeocystis pouchetii in antarctic coastal waters. Mar. Biol. 104: $339-346$

Guillard, R. R. L., Hellebust, J. (1971). Growth and the production of extracellular substances by two strains of Phaeocystis pouchetii. J. Phycol. 7: 330-338

Guillard, R. R. L., Ryther, J. H. (1962). Studies of marine planktonic diatoms. I. Cyclotella nana Hustedt, and Detonula confervaceax (Cleve) Gran. Can. J. Microbiol. 8: 229-239

Haas, L. W. (1982). Improved epifluorescent microscopic technique for observing planktonic micro-organisms. Ann. Inst. Oceanogr. Paris 58 (Suppl.): 261-66

Huntley, M., Tande, K. S., Eilertsen, H. C. (1987). On the trophic fate of Phaeocystis pouchetii. II. Grazing rates of Calanus hyperboreus feeding on diatoms and different size categories of P. pouchetii. J. exp. mar. Biol. Ecol. 110: $197-212$

Ishida, $Y$ (1968). Physiological studies on evolution of dimethyl sulfide from unicellular marine algae. Mem. Coll. Agr. Kyoto Univ. 94: 47-82

Kottmeier, S. T., McGrath Grossi, S., Sullivan, C. W. (1987) Sea ice microbial communities. VIII. Bacterial production in annual sea ice of McMurdo Sound, Antarctica. Mar Ecol. Prog. Ser. 35: 175-186

Laanbroek, H. J., Verplanke, J. C., de Visscher,P. R. M., de Vuyst, R. (1985). Distribution of phyto- and bacterioplankton growth and biomass parameters, dissolved inorganic nutrients and free amino acids during a spring bloom in the Oosterschelde basin, The Netherlands. Mar. Ecol. Prog. Ser. 25: 1-11.
Lancelot, C., Billen, G. (1984). Activity of heterotrophic bacteria and its coupling to primary production during the spring phytoplankton bloom in the southern bight of the North Sea. Limnol. Oceanogr. 29: 721-730

Lancelot, C., Mathot, S. (1985). Biochemical fractionation of primary production by phytoplankton in Belgian coastal waters during short- and long-term incubations with ${ }^{14} \mathrm{C}$ bicarbonate. II. Phaeocystis pouchetii colonial populations. Mar. Biol. 86: 227-232

Lancelot, C., Mathot, S. (1987). Dynamics of a Phaeocystisdominated spring bloom in Belgian coastal waters. I. Phytoplanktonic activities and related parameters. Mar. Ecol Prog. Ser. 37: 239-248

Lancelot, C., Billen, G., Sournia, A., Weisse, T., Colijn, F., Veldhuis, M. J. W., Davies, A., Wassmann, P. (1987) phaeocystis blooms and nutrient enrichment in the continental coastal zones of the North Sea. Ambio 16: 38-46

Larsen, R. J., Marx, M. L. (1986). An introduction to mathematical statistics and its applications. Prentice-Hall, Englewood Cliffs

Littlepage, J. L. (1965). Oceanographic investigations in McMurdo Sound, Antarctica. Antarctic. Res. Ser. 5: 1-37

Moisan, T., Putt, M., Stoecker, D. K. (1991). Bacterivory in McMurdo Sound: 2. Information from size-fractionation experiments. Antarctic J. U.S. 26: 141-143

Palmisano, A. C., SooHoo, J. B., SooHoo, S., Kottmeier, S. T. Craft, L. L., Sullivan, C. W. (1986). Photoadaptation in Phaeocystis pouchetii advected beneath annual sea ice in McMurdo Sound, Antarctica. J. Plankton Res. 8: 891-906

Parsons, T. R., Maita, Y., Lalli,C. M. (1984). A manual of chemical and biological methods for seawater analysis. Pergamon Press, Oxford

Peperzak, L. (1993). Daily irradiance governs growth rate and colony formation of Phaeocystis (Prymnesiophyceae). J. Plankton Res. 15: 809-821

Porter, K., Feig, Y (1980). The use of DAPI for identifying and counting aquatic microflora. Limnol. Oceanogr. 25 $943-948$

Putt, M. (1991). Abundance, chlorophyll content and photosynthetic rates of ciliates in the Nordic Seas during summer. Deep Sea Res. 37: 1713-1731

Putt, M., Borsheim, K. Y., Miceli, G., Stoecker, D. K. (1990). Seasonal changes in cell size and abundance of bacterioplankton during the Phaeocystis sp. bloom in McMurdo Sound. Antarctic J. U.S. 25: 199-200

Putt, M., Stoecker, D. K. (1989). An experimentally determined carbon:volume ratio for marine 'oligotrichous' ciliates from estuarine and coastal waters. Limnol. Oceanogr 34: $1097-1103$

Putt, M., Stoecker, D. K., Altstatt, J. (1991). Bacterivory in McMurdo Sound: 1. Grazing by heterotrophic nanoflagellates. Antarctir J. U.S 26. $139-141$

Rousseau, V., Mathot, S., Lancelot, C. (1990). Calculating carbon bimass of Phaeocystis sp. from microscopic observations. Mar. Biol. 107: 305-14

Savage, R. E., Hardy, A. C. (1934). Phytoplankton and the herring. Part I, 1921 to 1932. Fishery Invest. 2: 1-73

Sieburth, J. McN. (1959). Antibacterial activity of Antarctic marine phytoplankton. Limnol. Oceanogr. 4: 419-424

Sieburth, J. McN. (1960). Acrylic acid, an 'antibiotic' principle in Phaeocystrs blooms in Antarctic waters. Science 1.32: $676-677$

Sieburth, J. McN. (1961). Antibiotic properties of acrylic acid, a factor in the gastrointestinal antibiosis of polar marine animals. J. Bacteriol. 82: $72-78$

Smith, S. L. (1988). Copepods in Fram Strait in summer: distribution, feeding and metabolism. J. mar. Res. 46: 145-81 
Tande, K. S., Bamstedt, U. (1987). On the trophic fate of Phaeocystis pouchetii. I. Copepod feeding rates on solitary cells and colonies of $P$. pouchetii. Sarsia 72 : 313-320

Tukey, J. W. (1977). Exploratory data analysis. AddisonWesley Publishing Co., Reading

Veldhuis, M. J. W. Admiraal, W. (1985). Transfer of photosynthetic products in gelatinous colonies of Phaeocystis pouchetii (Haptophyceae) and its effect on the measurement of excretion rate. Mar. Ecol. Prog. Ser. 26: 301-304

Verity, P. G., Smayda, T. J. (1989). Nutritional value of Phaeocystis pouchetii (Prymnesiophyceae) and other phyto-

This article was submitted to the editor plankton for Acartia spp. (Copepoda): ingestion, egg production, and growth of nauplii. Mar. Biol. 100: 161-171

Verity, P. G., Villareal, T. A., Smayda, T. J. (1988). Ecological investigations of blooms of colonial Phaeocystis pouchetti II. The role of life-cycle phenomena in bloom termination J. Plankton Res. 10: 749-66

Wassmann, P., Vernet, M., Mitchell, B. G., Rey, F. (1990). Mass sedimentation of Phaeocystis pouchetii in the Barents Sea Mar. Ecol. Prog. Ser. 66: 183-195

Weisse, T., Scheffel-Moser, U. (1990). Growth and grazing loss rates in single-celled Phaeocystis sp. (Prymnesiophyceae). Mar. Biol. 106: 153-158

Manuscript first received: January 6, 1993

Revised version accepted: November 11, 1993 